\title{
Evaluation of phenolic profile, antioxidant and anticancer potential of two main representants of Zingiberaceae family against B164A5 murine melanoma cells
}

\author{
Corina Danciu ${ }^{1 \dagger}$, Lavinia Vlaia ${ }^{2 \dagger}$, Florinela Fetea ${ }^{3}$, Monica Hancianu ${ }^{4}$, Dorina E Coricovac ${ }^{5^{*}}$, Sorina A Ciurlea ${ }^{5}$, \\ Codruța M Şoica ${ }^{6}$, losif Marincu ${ }^{7 *}$, Vicentiu Vlaia ${ }^{8 *}$, Cristina A Dehelean ${ }^{4}$ and Cristina Trandafirescu ${ }^{6}$
}

\begin{abstract}
Background: Curcuma longa Linnaeus and Zingiber officinale Roscoe are two main representatives of Zingiberaceae family studied for a wide range of therapeutic properties, including: antioxidant, anti-inflammatory, anti-angiogenic, antibacterial, analgesic, immunomodulatory, proapoptotic, anti-human immunodeficiency virus properties and anticancer effects. This study was aimed to analyse the ethanolic extracts of Curcuma rhizome (Curcuma longa Linnaeus) and Zingiber rhizome (Zingiber officinale Roscoe) in terms of polyphenols, antioxidant activity and anti-melanoma potential employing the B164A5 murine melanoma cell line.
\end{abstract}

Results: In order to evaluate the total content of polyphenols we used Folin-Ciocâlteu method. The antioxidant activity of the two ethanolic extracts was determined by DPPH assay, and for the control of antiproliferative effect it was used MTT proliferation assay, DAPI staining and Annexin-FITC-7AAD double staining test. Results showed increased polyphenols amount and antioxidant activity for Curcuma rhizome ethanolic extract. Moreover, $100 \mathrm{\mu g} / \mathrm{ml}$ of ethanolic plant extract from both vegetal products presented in a different manner an antiproliferative, respectively a proapoptotic effect on the selected cell line.

Conclusions: The study concludes that Curcuma rhizome may be a promising natural source for active compounds against malignant melanoma.

Keywords: Curcuma longa Linnaeus, Zingiber officinale Roscoe, Polyphenols, Antioxidant, Melanoma

\section{Background}

For centuries, plants, plant products or pure active phytocompounds have been successfully used for the benefits of human health. Zingiberaceae family also known as ginger family comprises a number of approximately 52 genera and over 1300 species of aromatic plants [1].

\footnotetext{
*Correspondence: dorinacoricovac@umft.ro; imarincu@umftro; vlaiav@umft.ro ${ }^{\dagger}$ Equal contributors

${ }^{5}$ Department of Toxicology, Faculty of Pharmacy, University of Medicine and Pharmacy "Victor Babes", Eftimie Murgu Square, No. 2, Timisoara 300041 , Romania

${ }^{7}$ Faculty of Medicine, University of Medicine and Pharmacy "Victor Babes", Eftimie Murgu Square, No. 2, Timisoara 300041, Romania

${ }^{8}$ Department of Organic Chemistry, Faculty of Pharmacy, University of Medicine and Pharmacy "Victor Babes", Eftimie Murgu Square, No. 2, Timisoara 300041, Romania

Full list of author information is available at the end of the article
}

Among this high number of representatives some species have been reported for their therapeutic properties both in classical and ethno medicine [2]. Curcuma longa Linnaeus and Zingiber officinale Roscoe are two main representatives of Zingiberaceae family studied for a wide range of therapeutic properties. Curcuma longa Linnaeus, popular name-turmeric, is an aromatic, nutraceutical plant. The vegetal product of this plant, the root, have been intensively used, under different pharmaceutical formulations in Indian traditional medicine (Ayurveda) for different ailments, namely for wounds, acne, parasitic infection (local administration) and common cold, urinary tract disease and liver disease (systemic administration) [3]. Numerous experimental studies regarding the therapeutic activity of turmeric reported a plethora of pharmacological 
properties of this vegetal extract, including: antioxidant, anti-inflammatory, anti-angiogenic, antibacterial, analgesic, immunomodulatory, proapoptotic, anti-human immunodeficiency virus properties, being also studied in arthritis, diabetes, Alzheimer's disease [4-8]. The major active compound responsible for the pharmacodynamic action is the polyphenol curcumin $[9,10]$. Additionally, this natural polyphenol has been described as an anticancer agent, both in vitro and in vivo on a wide range of cancer types, such as colon, pancreatic, liver, cervical, pulmonary, thymic, brain, breast and bone cancer [11-13]. Recent studies intensively support the role of polyphenols in the prevention of degenerative diseases, like cardiovascular affections and cancers. Different fruits, vegetables, cereals, olive oil, chocolate and beverages, such as green tea, and red wine represent main sources of natural polyphenols $[14,15]$.

Together with turmeric, another exceedingly studied nutraceutical aromatic plant from Zingiberaceae family is Zingiber officinale Roscoe. Different types of extract from the root of ginger have been used in Ayurvedic and Chinese traditional herbal medicine in order to treat indigestion, vomiting, arthritis, rheumatism, pains, cramps, fever and infection [16]. The main pharmacological actions of active compounds extracted from ginger root reported by in vitro and in vivo test attributed to its active phytocompounds were: anti-inflammatory, antioxidant, antiemetic, anticancer, anticoagulant, immunomodulatory, antihyperglycemic, hypolipidemic, analgesic, and cardioprotective properties $[6,16-19]$. The main phytochemical constituents of the root, the vegetal product of this plant, responsible for the therapeutic action are gingerols, shogaols, paradols, gingerdiols, and zingerone $[6,20]$. Regarding its anticancer properties, recent studies have indicated a beneficial effect in case of liver, endometrial, ovarian and prostate cancer [21-24]. Furthermore, ginger was described as an anti-emetic agent in cancer chemotherapy [25]. Ginger was also reported to reduce the side effects of doxorubicin and cisplatin [26].

Skin cancers include basal cell carcinoma, squamous cell carcinoma and malignant melanoma. The first two types of skin cancer are the most frequent malignant neoplasms among fair-skinned population [27]. Recent studies report that in the last five decades the incidence of melanoma was also increasing especially in the case of white population [28]. Albeit malignant melanoma is less frequent than the other two types of skin cancer, is the most dangerous. It is responsible for most deaths due to its highly metastatic potential and resistance to chemotherapy [29]. One of the latest studies regarding the incidence in Europe shows that the highest rates are recorded in Nordic countries, especially in Switzerland, while Grece and other Mediterranean countries are at the opposite pole [30].
The aim of this study was to determine the total polyphenol content and the antioxidant activity of two ethanolic extracts obtained from the above mentioned species, and to perform preliminary in vitro tests regarding a possible antiproliferative and/or proapoptotic effect on murine melanoma cell line B164A5.

\section{Results}

\section{Polyphenols content of the two ethanolic extracts}

In the case of ethanolic extract obtained from Curcuma rhizome, the amount of polyphenols was $182 \pm 0.6 \mathrm{mg}$ GAE/g of dry plant material. A statistically significant decreased value was noticed in case of Zingiber rhizome ethanolic extract, namely $16 \pm 0.15 \mathrm{mg}$ GAE/g of dry plant material (Figure 1). Unpaired Student $t$ test was used to determine the statistical difference between the two groups, the results were statistically significant ( $\mathrm{p}$ value $=0.0097$ )

\section{Antioxidant capacity}

The investigation continued with the analysis of the antioxidant capacity of the two extracts. In this regard it was applied an assay based on the measurement of the reducing ability of antioxidants toward DPPH: Our results showed an increased antioxidant capacity for Curcuma rhizome ethanolic extract, $123.2 \pm 5 \mu \mathrm{M}$ T/100 g dry weight $(\mathrm{dw})$ extract as compared to Zingiber rhizome ethanolic extract where a value of $17.7 \pm 1.5 \mu \mathrm{M}$ T/100 g dry weight $(\mathrm{dw})$ (Figure 2). Unpaired Student $t$ test was used to determine the statistical difference between the two groups, the results were not statistically significant ( $\mathrm{p}$ value $=0.0249)$.

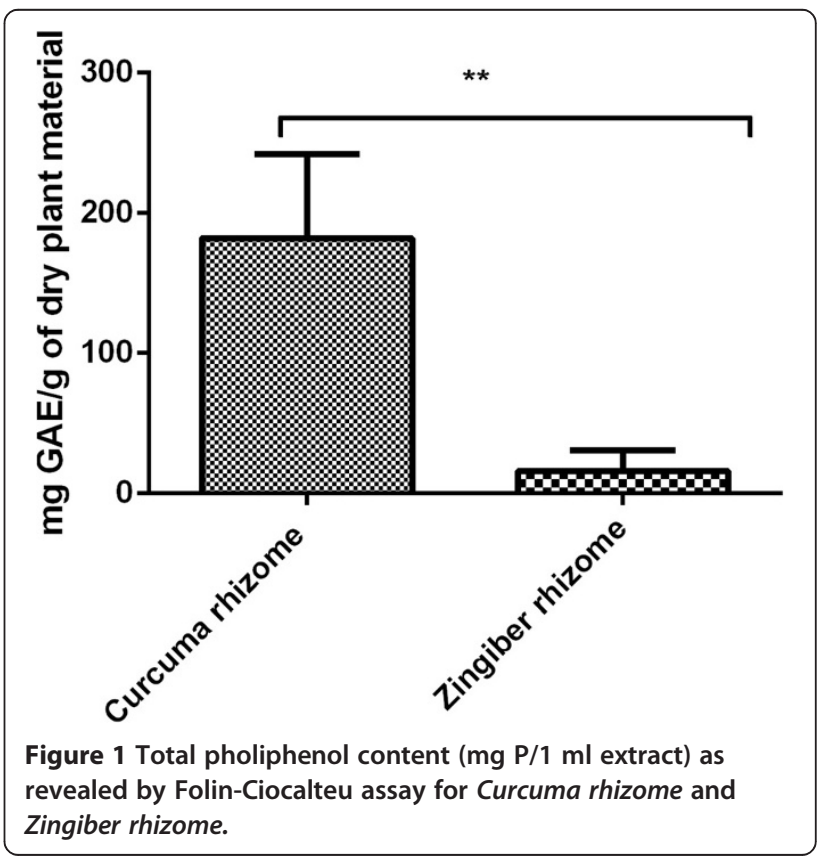




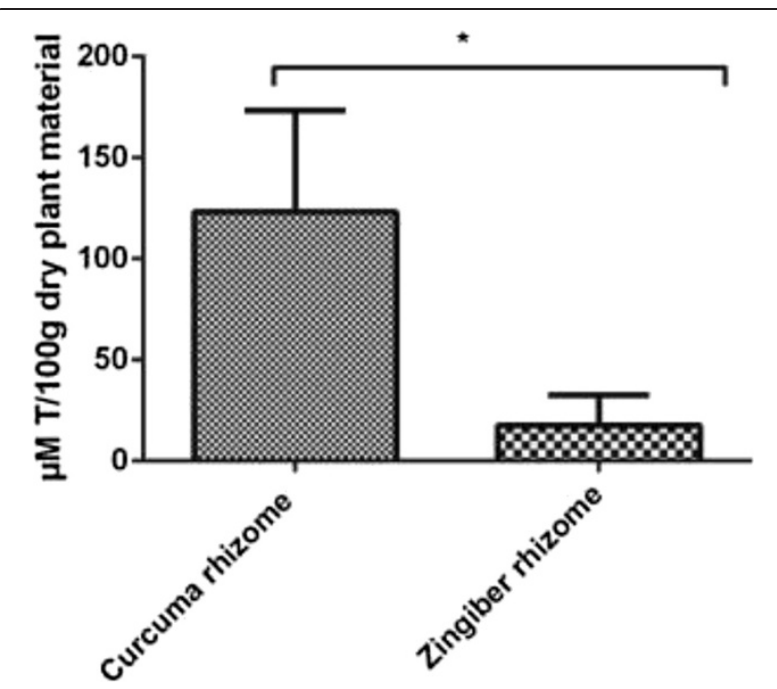

Figure 2 Antioxidant capacity (mM T/1 $\mathrm{ml}$ extract) as revealed by DPPH assay for Curcuma rhizome and Zingiber rhizome.

\section{Antiproliferative activity of the two ethanolic extracts} In order to observe a possible antiproliferative or even cytotoxic effect of the two analyzed samples on murine melanoma B164A5 cell line, MTT proliferation assay was conducted as described in the Material and Methods section. $100 \mu \mathrm{g} / \mathrm{ml}$ of plant ethanol extracts showed after a period of incubation of $48 \mathrm{~h}$ an inhibition index of $38 \pm 35$ for Curcuma rhizome extract while in case of Zingiber rhizome extract the inhibition index was $17 \pm 16$ (Figure 3). Unpaired Student $t$ test was used to determine the statistical difference between the two groups, the results were not statistically significant

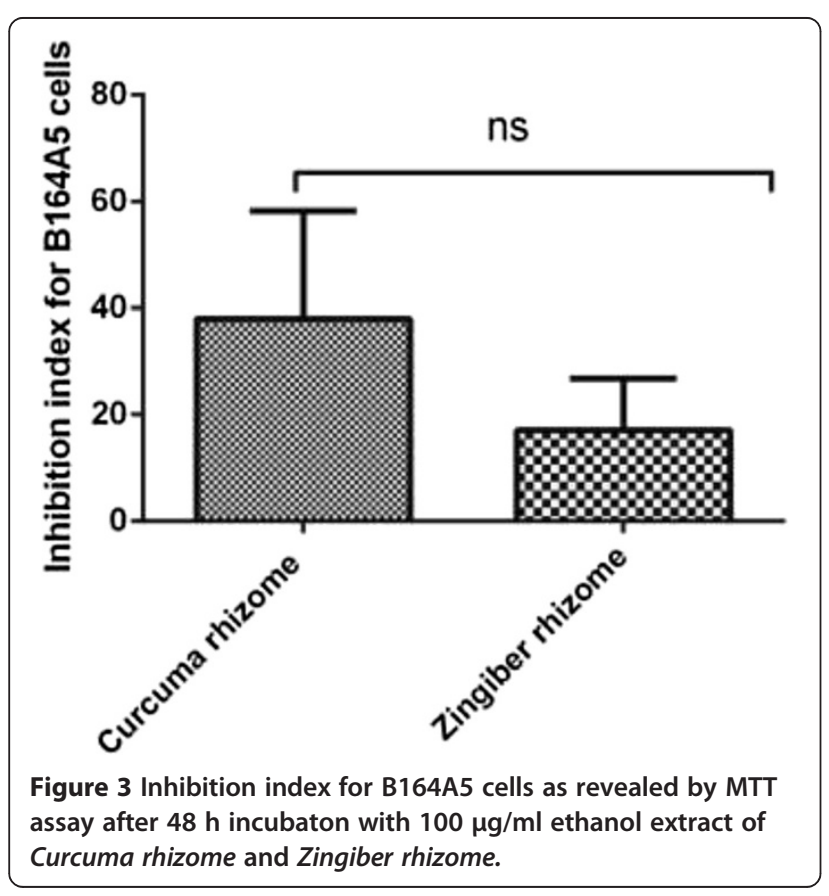

( $\mathrm{p}$ value $=0.4028$ ). Preliminary studies employing lower concentrations of extracts were performed but the inhibition index was to low in order to be depicted.

In addition, we decided to verify the apoptosis induced by the two ethanolic extracts on B164A5 cells using DAPI staining.After staining the cells with this reagent, the nucleus observed under fluorescent microscope was colored in blue. After $48 \mathrm{~h}$ incubation with the two extracts a number of cells presented nuclear fragmentation, condensed chromatin filaments or nuclear condensation as a sign of loss of cell membrane integrity. These characteristics were observed more frequently in case of the cells incubated with Curcume rhizome extract as compared to the ones incubated with Zingiber rhizome extract (Figure 4). Preliminary studies employing lower concentrations of extracts were performed but no or decreased signs of apoptosis could be detected.

In order to observe the apoptotic events (early apoptosis and late apoptosis) Annexin-FITC-7AAD double staining was performed. Results showed after an incubation period of $48 \mathrm{~h}$ a percentage of $5.935 \pm 1.5$ early apoptotic cells in case of Zingiber rhizome extract and $20.45 \pm 0.77$ early apoptotic cells in case of Curcuma rhizome extract. For late apoptotic cells the percentage was $10 \pm 1.4$ in case of Zingiber rhizome extract and $15.9 \pm 1.55$ in case of Curcuma rhizome extract (Figure 5). These results were statistically significant as revealed by Two-Way ANOVA followed by Bonferroni post test. Preliminary studies employing lower concentrations of extracts were performed but no or decreased signs of apoptosis could be detected.

\section{Discussions}

It is well known that natural polyphenols act as antioxidants therefore a diet rich in fruits, vegetables, cereals, extra virgin olive oil, red wine and tea (Mediterranean diet) would be of real practical interest in order to counteract some important pathologies like cardiovascular disease, some types of cancer, Alzheimer's disease, tooth decay or different infections $[15,31,32]$. Polyphenols are plant secondary metabolites and Curcuma rhizome and Zingiber rhizome have been reported as vegetal products that contain this type of phytochemicals [33-36]. It is well known that the amount of active agents is widely varying depending on the extraction conditions (solvent, temperature, extraction time) [37].

The aim of the present study was to analyze a possible anticancer potential of the two ethanolic extracts of curcuma and ginger root against B164A5 murine melanoma cell line. Extraction was performed by using ethanol as a solvent, solid: liquid ratio $1: 50$ at $70^{\circ} \mathrm{C}$ for $2 \mathrm{~h}$. The extraction conditions were chosen based on a previous study conducted by the group of Surojanametakul et al., who screened a wide range of parameters including solvent type, ratio and temperature, and have showed best results in terms of amount of extracted polyphenols [38]. 


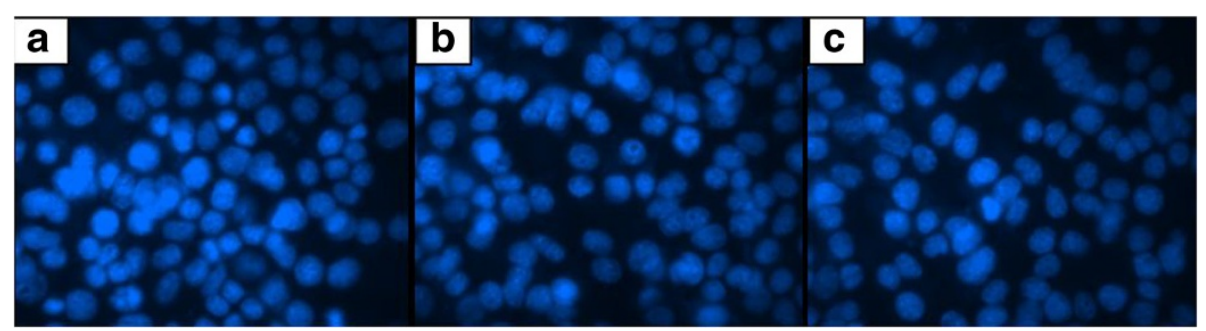

Figure 4 DAPI staining after $48 \mathrm{~h}$ incubaton of B164A5 cells with a) Medium; b) $100 \mu \mathrm{g} / \mathrm{ml}$ ethanol extract of Curcuma rhizome; c) $100 \mu \mathrm{g} / \mathrm{ml}$ ethanol extract of Zingiber rhizome.

In order to determine the amount of polyphenols we have chosen the Folin Ciocalteu assay. The procedure is convenient, simple, and reproducible [39]. Using other conditions not targeted to these two vegetal products, in a large screening study of 32 selected herbs, the group of Wojdyło et al., detected $172 \pm 0.12 \mathrm{mg} \mathrm{GAE} / \mathrm{g}$ of dry plant material for Curcuma rhizoma [40]. In the same conditions as the ones we have used the group of Surojanametakul et al., obtained for Curcuma rhizoma $146.65 \mathrm{mg} \mathrm{GAE} / \mathrm{g}$ of dry plant material [38]. Other values for Curcuma rhizoma polyphenols were reported by the group of Mongkolsilp et al., namely $122 \mathrm{mg} \mathrm{GAE} / \mathrm{g}$ of dry plant material [41]. For two varieties of root of Malaysian Zingiber officinale, namely Halia Bentong and Halia Bara, the group of Ghasemzadeh et al., recorded $10.22 \pm 0.87$ (Halia Bentong) and 13.5 \pm 2.26 (Halia Bara) polyphenols expressed as mg gallic acid/g of dry plant material [42]. The group of Otunola et al., reported a value of 22.09 total polyphenols expressed as $\mathrm{mg}$ gallic acid/g of dry plant material for ginger root [43].

Further investigations were conducted in order to determine the antioxidant capacity. We have measured the radical-scavenging activity of antioxidants against the free radical 1,1-diphenyl-2-picrylhydrazyl (DPPH).
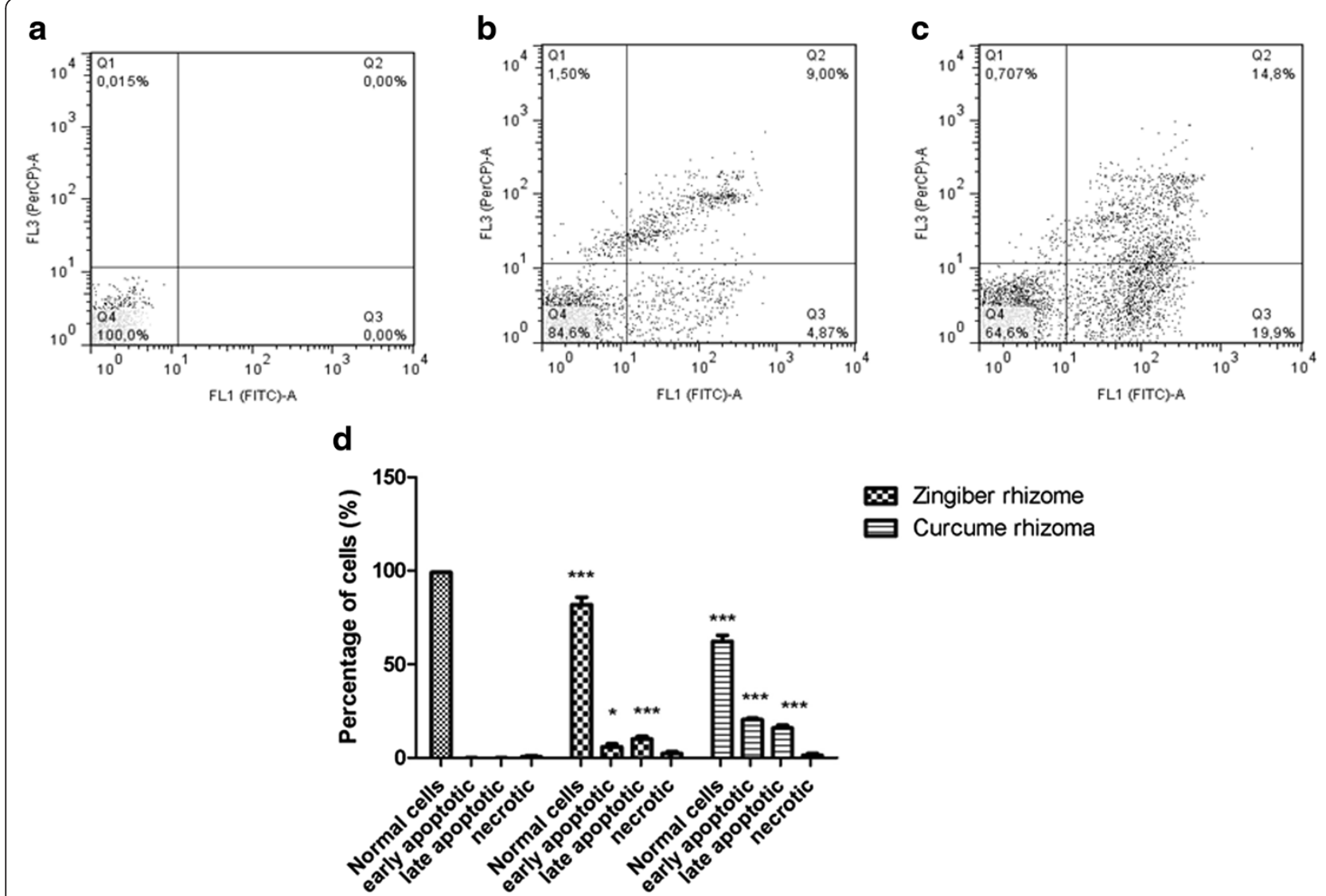

Figure 5 Annexin-FITC-7AAD double staining after $48 \mathrm{~h}$ incubaton of B164A5 cells with: a) Medium; b) $100 \mu \mathrm{g} / \mathrm{ml}$ ethanol extract of Curcuma rhizome; c) $100 \mu \mathrm{g} / \mathrm{ml}$ ethanol extract of Zingiber rhizome; d) The ensemble image together with statistical analyze of a,b,c. 
DPPH is a very common assay used to test the antioxidant capacity of vegetal extracts [44]. Results showed an increased antioxidant capacity for Curcuma rhizome ethanolic extract, as compared to Zingiber rhizome ethanolic extract. It can be observed a direct correlation between the amount of polyphenols detected in the selected vegetal products and the antioxidant capacity. Polyphenols have been intensively investigated for their antioxidant properties. It seems that the mechanism involves the modulation of oxidative stress [14].

To reach the final aim of our study we have screen for an antiproliferative, respectively proapoptotic effect of the two ethanolic extracts on the murine melanoma B164A5 cell line. As explained in the results section MTT proliferation assay revealed that at a dose of $100 \mu \mathrm{g} / \mathrm{ml}$ the extracts present antiproliferative capacity. Several reports regarding the antiproliferative activity of the two ethanolic extracts have been described in the literature, but none targeted towards B164A5 murinic melanoma cells.

Aqueous turmenic extracts were found to inhibit the proliferation of cultured bovine smooth muscle cells [45]. Curcuma longa extract was also found to inhibit the proliferation of rat's hepatic stellate cells [46]. Additionally it was reported that the extract has cytotoxic effect with different $\mathrm{IC}_{50 \mathrm{~s}}$ in breast and lung cancer cell lines $[47,48]$. Cytotoxicity was also observed in case of lymphocytes and Dalton's lymphoma [49]. Curcumin was found to sensitize pancreatic cancer cells to gemcitabine in vitro [50]. It was published that it inhibits proliferation and induce apoptosis in $\mathrm{LNCaP}$ prostate cancer cells in vivo [51]. Curcumin inhibits dose-dependent the SSC4-oral cancer cells, LoVo- human colorectal cancer cells, K1- papillary thyroid cancer cells, KKU100, KKU-M156, KKU-M213 - human biliary cancer cells [52-55]. Regarding melanoma, curcumin was reported as an antiproliferative agent on high metastatic B16F10 murinic melanoma cell line by targeting nucleotide phosphodiesterase 1A [56]. Furthermore curcumin was found to induce G2/M cell cycle arrest in case of human melanoma cells [57].

Ginger extract and 6-gingerol were found to inhibit the proliferation of rat colonic adenocarcinoma [58]. Moreover, it was proved that 10-shogaol, an important pharmacological compound from Zingiber officinale has the ability to promote growth of normal human skin cells [59]. Additionally literature reports G0/G1 arrest and apoptosis induced by ginger extract in case of HCT 116 and HT 29 colon cancer cell lines [60]. Chemopreventive efficacy of ginger extract was also described against hepatoma HepG2 and HLE cell lines [22]. Furthermore, aqueous extract of ginger was proclaimed to present antiproliferative activity in case of human non-small lung epithelium cancer (A549) cells and human cervical epithelial carcinoma (HeLa) [61].
The group of Lea et al., published that ginger extract is active on some cancer cell lines like ovary -OVCAR and leukemia - K562, but not significantly active in case of other cancer cell lines like breast-MCF7, colon HT29, lung NCI460, prostate PCO3 and melanoma UACC62 [58,62].

Due to the fact that apoptosis is in balance with proliferation, we have also investigated a possible proapoptotic effect of selected extracts. DAPI staining was useful in order to observe first insights of apoptosis, but real quantification of both early and late apoptotic cells has been done by double staining Annexin-FITC-7AAD. As explained in the results section these assays revealed that at a dose of $100 \mu \mathrm{g} / \mathrm{ml}$ the extracts present proapoptotic capacity.

Curcuma aqueous extract was proclaimed with a proapoptotic activity against human colon carcinoma LS-174-T cells [63]. Turmerone, extracted by supercritical carbon dioxide was noted to induce apoptosis in hepatocellular carcinoma HepG2 cells [46]. The group of Ozaki et al., demonstrated the role of curcumin in the induction of rabbit osteoclast apoptosis along with inhibition of bone resorption [64]. Curcumin was previously reported for its proapoptotic activity in human lung carcinoma A549 cells, NPC-TW 076, human nasopharyngeal carcinoma cells, human colon cancer colo 205 cells, murine myelomonocytic leukemia WEHI-3 cells, leukaemic Jurkat cells [63,65-67]. Curcumin was described as a proapoptotic agent against different human melanoma cells $[57,68]$.

On the other hand, ginger extract was reported to trigger apoptosis in case of HCT 116 and HT 29 colon cancer cell lines [60]. Zerumbone, an active agent from Zingiber aromaticum was describd as a dose-dependent proapoptotic agent in case of HT-29, CaCo-2, and MCF-7 cancer cells [69]. Ethanolic extract of Zingiber officinale triggered apoptosis in case of $\mathrm{HepG}_{2}$ - human hepatoma cell line [70]. [6] -paradol, a minor constituent of ginger and other related derivates were demonstrated to induce apoptosis in case of oral squamous carcinoma cell line $\mathrm{KB}$ and human promyelocytic leukemia (HL-60) cells [71,72]. In addition, [6]-gingerol, the main pharmacologically active principle from ginger root was reported to induce apoptosis in case of SCC-25 oral cavity cancer cell line, different human colorectal cancer cells, human cervical cancer HeLa cells and human promyelocytic leukemia (HL-60) cells [72-75]. Furthermore, terpenoids present in steam distilled extract of ginger had the capacity to induce apoptosis in endometrial cancer cells via p53 activation [22]. [6]-gingerol was reported to inhibit melanogenesis in B16F10 melanoma cells [76].

\section{Conclusions}

The present study can be considered of practical interest since our results supplement the data existing in the literature with new information regarding the antiproliferative, respectively proapoptotic effect of the selected extracts on 
murine melanoma B164A5 cell line. To the best of our knowledge this report was never done before. It is obvious that Curcuma rhizome ethanolic extract presented an increased effect in comparison with Zingiber rhizome ethanolic extract on B164A5 murine melanoma cell line regarding both proliferation and apoptosis. The increased anticancer activity may be correlated with the higher amount of polyphenols, respectively increased antioxidant capacity as detected by Folin Ciocalteu and DPPH assay. These preliminary findings are of great interest and further studies will be developed in order to characterize the extract and find pure active phytoconstituents that in a proper dose may exercise an increased antimelanoma activity. As a clear conclusion presented results indicate that Curcuma rhizome, a main representant of Zingiberaceae family may be a promising natural source for active compounds against malignant melanoma.

\section{Methods}

\section{Vegetal extracts}

Curcuma rhizome (Curcuma longa Linnaeus) and Zingiber rhizome (Zingiber officinale Roscoe) were achieved from University of Agricultural Sciences and Veterinary Medicine, Timisoara, Romania, Department of Plant Culture. Fresh rhizomes of both turmeric and ginger were cleaned, washed with deionised water, sliced and dried in the sun for one week, and dried again at $50^{\circ} \mathrm{C}$ in a drying stove for 6 hours. Dried rhizomes were cut in small pieces, and powdered by electronic mill. Extraction was performed by using ethanol as a solvent, solid: liquid ratio 1:50 at $70^{\circ} \mathrm{C}$ for $2 \mathrm{~h} \mathrm{[38].}$

The formal identification of the plant material was done by the specialist in the field Dr. Senior Lecturer Danciu Corina, Department of Pharmacognosy, Faculty of Pharmacy, University of Medicine and Pharmacy Victor Babes, Timisoara.A voucher specimen of this material has been deposited in a herbarium, available at UMFT Victor Babes, Timisoara-Department of Pharmacognosy, No. Ph-28.17.

\section{Total polyphenolic content}

Total polyphenolic content of selected vegetal products was determined by Folin Ciocalteu assay. The method is based on the measurement of optical density of a primer extract which by complexation with the Folin-Ciocalteu reagent absorbs in the visible domain at $\lambda=720 \mathrm{~nm}$ (multidetection Biotec spectofotometer, UV-VIS 190-900 nm). The necessary reagents are: bidistilled water, Folin Ciocalteu reagent (Merck, Romania), $\mathrm{Na}_{2} \mathrm{CO}_{3}$ (sodium bicarbonate) and ethanol (Sigma Aldrich, Romania). The assay was conducted on a microplate with 24 wells and the following quantities of reagents were used: $23 \mu \mathrm{l}$ sample; $115 \mu \mathrm{l}$ Folin Ciocalteu reagent; $345 \mu \mathrm{l}$ $\mathrm{Na}_{2} \mathrm{CO}_{3}(7.5 \%)$ and $1.817 \mathrm{ml}$ bidistilled water. Standard curve was done using different concentrations of gallic acid $(\mathrm{mg} / \mathrm{ml})$ as standard. Absorption at $765 \mathrm{~nm}$ was measured. Total phenol contents were expressed in gallic acid (Sigma Aldrich, Germany) equivalents (mg gallic acid/g dry weight - DW). All determinations were performed in triplicate.

\section{Antioxidant capacity (DPPH assay)}

This assay is based on the measurement of the reducing ability of antioxidants toward DPPH (2, 2' diphenyl-1picrylhydrazyl) radical. The DPPH radical-scavenging activity was determined using the method proposed by Brand-Williams et al. [77]. The assay was conducted on a microplate with 24 wells. DPPH $(80 \mu \mathrm{M})$ was dissolved in pure ethanol (98\%). The radical stock solution was prepared fresh. The mixture was shaken vigorously and allowed to stand at room temperature in the dark for $10 \mathrm{~min} .200 \mu \mathrm{l}$ of sample with $1.4 \mathrm{ml}$ radical solution were added to each microplate well. The decrease in absorbance of the resulting solution was monitored at $515 \mathrm{~nm}$ for $30 \mathrm{~min}$. The results were corrected for dilution and expressed in $\mu \mathrm{M}$ Trolox ((S)-(-)-6-hydroxy-2,5,7,8tetramethylchroman-2- carboxylic acid) (Sigma Aldrich, Germany) per $100 \mathrm{~g}$ dry weight (DW). All determinations were performed in triplicate.

\section{B164A5 melanoma cells}

B164A5 cells were acquired from Sigma Aldrich (ECACC, origin Japan stored UK). The complete growth medium (culture medium) for this cells is DMEM (Dulbecco's Modified Eagle's Medium), supplemented with 10\% FCS (Fetal Calf Serum), 1\% Penicillin/Streptomycin mixture (Pen/Strep, $10.000 \mathrm{IU} / \mathrm{ml}$ ) and 2\% HEPES (4-(2-hydroxyethyl)-1-piperazineethanesulfonic acid). The cells were cultured by incubation at $37^{\circ} \mathrm{C}$ in $5 \%$ $\mathrm{CO}_{2}$ atmosphere. At a confluence of $70-80 \%$ (every two or three days) the cells were passed using $0.25 \%$ Trypsin $1 \mathrm{mM}$ EDTA solution followed by centrifugation (5 minutes, $1200 \mathrm{rpm}$ ) and replated in T75 culture flasks at a subcultivation ratio of 1:10 to ensure optimal proliferation.

\section{MTT proliferation assay}

MTT kit was acquired from Roche, Germany. $100 \mu \mathrm{l}$ cell suspension containing $6 \times 10^{3}$ B164A5 melanoma cells were seeded onto a 96-well microplate and attached to the bottom of the well overnight. Afterwards $100 \mu \mathrm{l}$ of new medium containing 10\% FCS and $100 \mu \mathrm{g} / \mathrm{ml}$ of plant ethanol extracts were added. After $48 \mathrm{~h}$ of incubation, $10 \mu \mathrm{l}$ of MTT reagent from a stock solution of $5 \mathrm{mg} / \mathrm{ml}$ were added. The intact mitochondrial reductase converted and precipitated MTT as purple crystals during a $4 \mathrm{~h}$ contact period. After four hours the precipitated crystals were dissolved in $100 \mu \mathrm{l}$ of solubilisation solution. Finally, 
the reduced MTT was spectrophotometrically analyzed at $570 \mathrm{~nm}$, using a reference of $656 \mathrm{~nm}$ using an ELISA reader. Inhibition index was calculated as 1-absorbance sample X/absorbance sample blank.

\section{DAPI (4, 6-Diamidino-2-phenylindole) staining}

B16 cells were seeded at a concentration of $5 \times 10^{4}$ in a chamber slide system formed of 8 well glass slides in culture medium. After $24 \mathrm{~h}$ cells were incubated in medium containing $10 \% \mathrm{FCS}$ and $100 \mu \mathrm{g} / \mathrm{ml}$ of plant ethanol extracts. The total volume added in chamber was $400 \mu$ l. Cells were incubated for $48 \mathrm{~h}$ and afterwards the medium was removed. Cells were washed with PBS and afterwards $400 \mu \mathrm{l}$ of staining solution were added in each well. The staining solution consisted of a mixture of methanol and DAPI (Roche) as follows: $1 \mathrm{ml}$ methanol: $2 \mu \mathrm{l}$ DAPI (from a stock solution of $1 \mathrm{mg} / \mathrm{ml}$ ). Cells were incubated for 5 minutes with this staining solution and afterwards washed with PBS and analyzed by fluorescence microscopy.

\section{Annexin-FITC-7AAD double staining}

Cells were cultivated in a 6 well plates at a density of $80 \%$ using normal medium. After $24 \mathrm{~h}$ medium containing $10 \% \mathrm{FCS}$ and $100 \mu \mathrm{g} / \mathrm{ml}$ of plant ethanol extracts were added. After $48 \mathrm{~h}$ cells were detached using trypsin, washed with ice cold PBS and resuspended in $500 \mu \mathrm{l}$ Annexin binding buffer (1.19 g HEPES $\mathrm{NaOH} \mathrm{pH}=7.4$; $4.09 \mathrm{~g} \mathrm{NaCl} ; 0.138 \mathrm{~g} \mathrm{CaCl}_{2}$ in $50 \mathrm{ml}$ distillated water and diluted 1:10) at a concentration of $1 \times 10^{6}$ cells $/ \mathrm{ml}$. Cells were centrifugate $5 \mathrm{~min}$ at $1200 \mathrm{rpm}$, the supernatant was discarded and the cells were resuspended in $70 \mu \mathrm{l}$ of Annexin binding buffer. $5 \mu \mathrm{l}$ Annexin V-FITC (ImmunoTools) and $5 \mu \mathrm{l}$ 7AAD (ImmunoTools) were added and cells were incubated $15 \mathrm{~min}$ on ice and in the dark. Samples were measured by FACS on FL1 and FL3 fluorescence channels using a BD Canto II FACS DIVA device. Untreated cells were used as negative control and cells treated with $500 \mathrm{nM}$ staurosporine (LC laboratories) for $24 \mathrm{~h}$ were used for the compensations. Flow Jo soft (7.6.3) was used for data analysis.

\section{Statistics}

Unpaired Student $\mathrm{t}$ test or Two-Way ANOVA followed by Bonferroni post test were used to determine the statistical difference between various experimental and control groups.", *** and ***: indicate $\mathrm{p}<0.05, \mathrm{p}<0.01$ and $\mathrm{p}<0.001$ compared to control group. Results are presented as mean \pm standard deviation (SD).

\section{Abbreviations}

DW: Dry weight; DPPH, 2: 2' diphenyl-1-picrylhydrazyl; DMEM: Dulbecco's Modified Eagle's Medium; FCS: Fetal Calf Serum; HEPES: 4-(2-hydroxyethyl)-1piperazineethanesulfonic acid; DAPI: 4, 6-Diamidino-2-phenylindole; PBS: Phosphate buffered saline; GAE: Gallic acid equivalents; B164A5: Murine melanoma cells.

\section{Competing interests}

The authors declare that they have no competing interests.

\section{Authors' contributions}

$\mathrm{CD}, \mathrm{W}, \mathrm{MH}$ and FF performed the experiments, analyzed/interpreted data and drafted the manuscript. DEC, SAC, CMS and IM analyzed/interpreted data. W, CD and CT conceived the study, the experiments, also analyzed/interpreted data and finalized the manuscript. All co-authors reviewed and discussed the paper. All authors read and approved the final manuscript.

\section{Acknowledgments}

This study was published under the frame of European Social Found, Human Resources Development Operational Programme 2007-2013, project no. POSDRU/159/1.5/S/136893 obtained by postdoc. Danciu Corina.

\section{Author details}

'Department of Pharmacognosy, Faculty of Pharmacy, University of Medicine and Pharmacy Victor Babes", Eftimie Murgu Square, No. 2, Timisoara 300041, Romania. ${ }^{2}$ Department of Pharmaceutical Technology, Faculty of Pharmacy, University of Medicine and Pharmacy Victor Babes", Eftimie Murgu Square, No. 2, Timisoara 300041, Romania. ${ }^{3}$ Department of Chemistry and Biochemistry, University of Agricultural Sciences and Veterinary Medicine of Cluj-Napoca, Mănăştur Str.,No. 3-5, Cluj-Napoca 400372, Romania. ${ }^{4}$ Department of Pharmacognosy, Faculty of Pharmacy, University of Medicine and Pharmacy "Gr.T.Popa", lasi, Romania. ${ }^{5}$ Department of Toxicology, Faculty of Pharmacy, University of Medicine and Pharmacy "Victor Babes", Eftimie Murgu Square, No. 2, Timisoara 300041, Romania. 'Department of Pharmaceutical Chemistry, Faculty of Pharmacy, University of Medicine and Pharmacy "Victor Babes", Eftimie Murgu Square, No. 2, Timisoara 300041, Romania. ${ }^{7}$ Faculty of Medicine, University of Medicine and Pharmacy "Victor Babes", Eftimie Murgu Square, No. 2, Timisoara 300041, Romania. ${ }^{8}$ Department of Organic Chemistry, Faculty of Pharmacy, University of Medicine and Pharmacy "Victor Babes", Eftimie Murgu Square, No. 2, Timisoara 300041, Romania.

Received: 9 July 2014 Accepted: 4 December 2014 Published: 12 January 2015

\section{References}

1. Kress WJ, Prince LM, Williams KJ. The phylogeny and a new classification of the gingers (Zingiberaceae): evidence from molecular data. Am J Bot. 2002;89:1682-96.

2. Tushar, Basak S, Sarma GC, Rangan L. Ethnomedical uses of Zingiberaceous plants of Northeast India. J Ethnopharmacol. 2010;132:286-96.

3. Chainani-Wu N. Safety and anti-inflammatory activity of curcumin: a component of tumeric (Curcuma longa). J Altern Complement Med. 2003;9:161-8.

4. Araújo CC, Leon LL. Biological activities of Curcuma longa L. Mem Inst Oswaldo Cruz. 2011;96:723-8.

5. Boaz M, Leibovitz E, Dayan YB, Wainstein J. Functional foods in the treatment of type 2 diabetes: olive leaf extract, turmeric and fenugreek, a qualitative review. Funct Foods Health Dis. 2011;1:472-81.

6. Mishra S, Palanivelu K. The effect of curcumin (turmeric) on Alzheimer's disease: an overview. Ann Indian Acad Neurol. 2008;11:13-9.

7. Ramadan G, Al-Kahtani MA, El-Sayed WM. Anti-inflammatory and antioxidant properties of Curcuma longa (turmeric) versus Zingiber officinale (ginger) rhizomes in rat adjuvant-induced arthritis. Inflammation. 2011;34:291-301.

8. Ringman JM, Frautschy SA, Cole GM, Masterman DL, Cummings JL. A potential role of the curry spice curcumin in Alzheimer's disease. Curr Alzheimer Res. 2005;2:131-6.

9. Sharma RA, Gescher AJ, Steward WP. Curcumin: the story so far. Eur J Cancer. 2005:41:1955-68.

10. Maheshwari RK, Singh AK, Gaddipati J, Srimal RC. Multiple biological activities of curcumin: a short review. Life Sci. 2006;78:2081-7.

11. Bar-Sela G, Epelbaum R, Schaffer M. Curcumin as an anti-cancer agent: review of the gap between basic and clinical applications. Curr Med Chem. 2010;17:190-7.

12. Darvesh AS, Aggarwal BB, Bishayee A. Curcumin and liver cancer: a review. Curr Pharm Biotechnol. 2012;13:218-28.

13. Shehzad A, Lee J, Lee YS. Curcumin in various cancers. Biofactors. 2013;39:56-68. 
14. Scalbert A, Johnson IT, Saltmarsh M. Polyphenols: antioxidants and beyond Am J Clin Nutr. 2005:81:215S-7.

15. D'Archivio M, Filesi C, Di Benedetto R, Gargiulo R, Giovannini C, Masella R. Polyphenols, dietary sources and bioavailability. Ann Ist Super Sanita. 2007:43:348-61.

16. Ali BH, Blunden G, Tanira MO, Nemmar A. Some phytochemical, pharmacological and toxicological properties of ginger (Zingiber officinale Roscoe): a review of recent research. Food Chem Toxicol. 2008:46:409-20.

17. Nicoll R, Henein MY. Ginger (Zingiber officinale Roscoe): a hot remedy for cardiovascular disease? Int J Cardiol. 2009;131:408-9.

18. Li Y, Tran VH, Duke CC, Roufogalis BD. Preventive and protective properties of zingiber officinale (ginger) in diabetes mellitus, diabetic complications, and associated lipid and other metabolic disorders: a brief review. Evid Based Complement Altern Med. 2012:2012:516870.

19. Siddaraju MN, Dharmesh SM. Inhibition of gastric $\mathrm{H}+, \mathrm{K}+-$ ATPase and Helicobacter pylori growth by phenolic antioxidants of Zingiber officinale. Mol Nutr Food Res. 2007:51:324-32.

20. Wilson R, Haniadka R, Sandhya P, Palatty PL, Baliga MS. Ginger (Zingiber officinale Roscoe) the Dietary Agent in Skin Care: A Review. In: Watson RR, Zibadi S, editors. Bioactive Dietary Factors and Plant Extracts in Dermatology. Karnataska: Humana Press; 2013. p. 103-11.

21. Habib SH, Makpol S, Hamid NAA, Das S, Ngah WZ, Yusof YA. Ginger extract (Zingiber Officinale) has anti-cancer and anti-inflammatory effects on ethionine-induced hepatoma rats. Clinics. 2008;63:807-13.

22. Liu Y, Whelan RJ, Pattnaik BR, Ludwig K, Subudhi E, Rowland H, et al. Terpenoids from Zingiber officinale (Ginger) induce apoptosis in endometrial cancer cells through the activation of p53. PLoS One. 2012;7: e53178. doi:10.1371/journal.pone.0053178.

23. Rhode J, Fogoros S, Zick S, Wahl H, Griffith KA, Huang J, et al. Ginger inhibits cell growth and modulates angiogenic factors in ovarian cancer cells. BMC Complement Altern Med. 2007;7:44.

24. Brahmbhatt M, Gundala SR, Asif G, Shamsi SA, Aneja R. Ginger phytochemicals exhibit synergy to inhibit prostate cancer cell proliferation. Nutr Cancer. 2013;65:263-372.

25. Haniadka R, Rajeev AG, Palatty PL, Arora R, Baliga MS. Zingiber officinale (ginger) as an anti-emetic in cancer chemotherapy: a review. J Altern Complement Med. 2012;18:440-4.

26. Pereira MM, Haniadka R, Chacko PP, Palatty PL, Baliga MS. Zingiber officinale Roscoe (ginger) as an adjuvant in cancer treatment: a review. J BUON. 2011;16:414-24.

27. Saladi RN, Persaud AN. The causes of skin cancer: a comprehensive review. Drugs Today. 2005;41:37-53.

28. Erdmann F, Lortet-Tieulent J, Schüz J, Zeeb H, Greinert R, Breitbart EW, et al. International trends in the incidence of malignant melanoma 1953-2008-are recent generations at higher or lower risk? Int J Cancer. 2013;132:385-400.

29. Wang L, Shi Y, Ju P, Liu R, Yeo SP, Xia Y, et al. Silencing of diphthamide synthesis 3 (Dph3) reduces metastasis of murine melanoma. PLoS One. 2012; :e49988.

30. Forsea AM, Del Marmol V, de Vries E, Bailey EE, Geller AC. Melanoma incidence and mortality in Europe: new estimates, persistent disparities. Br J Dermatol. 2012;167:1124-30.

31. Santangelo C, Vari R, Scazzocchio B, Di Benedetto R, Filesi C, Masella R. Polyphenols, intracellular signalling and inflammation. Ann Ist Super Sanita. 2007:43:394-405

32. Ferrazzano G, Amato I, Ingenito A, Zarrelli A, Pinto G, Pollio A. Plant polyphenols and their anti-cariogenic properties: a review. Molecules. 2011;16:1486-507.

33. Avwioro OG, Onwuka SK, Moody JO, Agbedahunsi JM, Oduola T, Ekpo OE, et al. Curcuma longa extract as a histological dye for collagen fibres and red blood cells. J Anat. 2007;210:600-3.

34. Prathapan A, Lukhman M, Arumughan C, Sundaresan A, Raghu KG. Effect of heat treatment on curcuminoid, colour value and total polyphenols of fresh turmeric rhizome. Int J Food Sci Technol. 2009:44:1438-44.

35. Miquel J, Bernd A, Sempere JM, Díaz-Alperi J, Ramírez A. The curcuma antioxidants: pharmacological effects and prospects for future clinical use. A review. Arch Gerontol Geriatr. 2002;34:37-46.

36. Ancy J, Thayumanavan B, Pournami PR. Characterization of polyphenol oxidase in ginger (Zingiber officinale R.). J Spices and Aromatic Crops. 2012;21:33-41.

37. Sasidharan S, Chen Y, Saravanan D, Sundram KM, Yoga Latha L. Extraction, isolation and characterization of bioactive compounds from plants' extracts. Afr J Tradit Complement Altern Med. 2010;8:1-10.
38. Surojanametakul V, Satmalee P, Saengprakai J, Siliwan D, Wattanasiritham L. Preparation of curcuminoid powder from turmeric root (Curcuma Longa Linn) for food ingredient Use. Kasetsart J (Nat Sci). 2010;44:123-30.

39. Cirilo G, lemma F. Antioxidant Polymers: Synthesis, Properties, and Applications. Calabria: John Wiley \& Sons; 2012.

40. Wojdyło A, Oszmiański J, Czemerys R. Antioxidant activity and phenolic compounds in 32 selected herbs. Food Chem. 2007;105:940-9.

41. Mongkolsilp S, Pongbupakit I, Sae-Lee N, Sitthihawom W. Radical scavenging activity and total phenolic content of medicinal plants used in primary health care. SWU J Pharm Sci. 2004;9:32-5.

42. Ghasemzadeh A, Jaafar HZE, Rahmat A. Antioxidant activities, total phenolics and flavonoids content in two varieties of Malaysia young ginger (Zingiber officinale Roscoe). Molecules. 2010;15:4324-33.

43. Otunola GA, Afolayan AJ. Evaluation of the polyphenolic contents and antioxidant properties of aqueous extracts of garlic, ginger, cayenne pepper and their mixture. J Applied Bot Food Qual. 2013:86:66-70.

44. Pyrzynska K, Pękal A. Application of free radical diphenylpicrylhydrazyl (DPPH) to estimate the antioxidant capacity of food samples. Anal Methods. 2013:5:4288-95.

45. Zhang W, Liu D, Wo X, Zhang Y, Jin M, Ding Z. Effects of Curcuma Longa on proliferation of cultured bovine smooth muscle cells and on expression of low density lipoprotein receptor in cells. Chin Med J. 1999;112:308-11.

46. Cheng SB, Wu LC, Hsieh YC, Wu CH, Chan YJ, Chang LH, et al. Supercritical carbon dioxide extraction of aromatic turmerone from Curcuma longa Linn. induces apoptosis through reactive oxygen species-triggered intrinsic and extrinsic pathways in human hepatocellular carcinoma HepG2 Cells. J Agric Food Chem. 2012;60:9620-30.

47. Ranjbari J, Alibakhshi A, Arezumand R, Pourhassan-Moghaddam M, Rahmati M, Zarghami $\mathrm{N}$, et al. Effects of curcuma Longa extract on telomerase activity in lung and breast cancer cells. Zahedan J Res Med Sci. 2013;16:29-34.

48. Mohammad P, Nosratollah Z, Mohammad R, Abbas A, Javad R. The inhibitory effect of Curcuma longa extract on telomerase activity in A549 lung cancer cell line. Afr J Biotechnol. 2010;9:912-9.

49. Kuttan R, Bhanumathy P, Nirmala K, George MC. Potential anticancer activity of turmeric (Curcuma longa). Cancer Lett. 1985;29:197-202.

50. Kunnumakkara AB, Guha S, Krishnan S, Diagaradjane P, Gelovani J, Aggarwal BB. Curcumin potentiates antitumor activity of gemcitabine in an orthotopic model of pancreatic cancer through suppression of proliferation, angiogenesis, and inhibition of nuclear factor-kappaB-regulated gene products. Cancer Res. 2007;67:3853-61.

51. Dorai T, Cao YC, Dorai B, Buttyan R, Katz AE. Therapeutic potential of curcumin in human prostate cancer. III. Curcumin inhibits proliferation, induces apoptosis, and inhibits angiogenesis of LNCaP prostate cancer cells in vivo. Prostate. 2001;47:293-303.

52. Chen JW, Tang YL, Liu H, Zhu ZY, Lü D, Geng N, et al. Anti-proliferative and anti-metastatic effects of curcumin on oral cancer cells. Hua Xi Kou Qiang Yi Xue Za Zhi. 2011:29:83-6.

53. Guo L, Chen XJ, Hu YH, Yu ZJ, Wang D, Liu JZ. Curcumin inhibits proliferation and induces apoptosis of human colorectal cancer cells by activating the mitochondria apoptotic pathway. Phytother Res. 2013;27:422-30.

54. Song F, Zhang L, Yu HX, Lu RR, Bao JD, Tan C, et al. The mechanism underlying proliferation-inhibitory and apoptosis-inducing effects of curcumin on papillary thyroid cancer cells. Food Chem. 2012;132:43-50.

55. Prakobwong S, Gupta SC, Kim JH, Sung B, Pinlaor P, Hiraku Y, et al. Curcumin suppresses proliferation and induces apoptosis in human biliary cancer cells through modulation of multiple cell signaling pathways. Carcinogenesis. 2011;32:1372-80.

56. Abusnina A, Keravis T, Yougbaré I, Bronner C, Lugnier C. Anti-proliferative effect of curcumin on melanoma cells is mediated by PDE1A inhibition that regulates the epigenetic integrator UHRF1. Mol Nutr Food Res. 2011;55:1677-89.

57. Zheng M, Ekmekcioglu S, Walch ET, Tang CH, Grimm EA. Inhibition of nuclear factor-kappaB and nitric oxide by curcumin induces G2/M cell cycle arrest and apoptosis in human melanoma cells. Melanoma Res. 2004;14:165-71.

58. Brown AC, Shah C, Liu J, Pham JT, Zhang JG, Jadus MR. Ginger's (Zingiber officinale Roscoe) inhibition of rat colonic adenocarcinoma cells proliferation and angiogenesis in vitro. Phytother Res. 2009;23:640-5.

59. Chen CY, Cheng KC, Chang AY, Lin YT, Hseu YC, Wang HM. 10-shogaol, an antioxidant from zingiber officinale for skin cell proliferation and migration enhancer. Int J Mol Sci. 2012;13:1762-77. 
60. Abdullah S, Abidin SAZ, Murad NA, Makpol S, Ngah WZW, Yusof YAM. Ginger extract (Zingiber officinale) triggers apoptosis and G0/G1 cells arrest in HCT 116 and HT 29 colon cancer cell lines. Afr J Biochem Res. 2010:4:134-42

61. Choudhury D, Das A, Bhattacharya A, Chakrabarti G. Aqueous extract of ginger shows antiproliferative activity through disruption of microtubule network of cancer cells. Food Chem Toxicol. 2010;48:2872-80.

62. Leal PF, Braga ME, Sato DN, Carvalho JE, Marques MO, Meireles MA. Functional properties of spice extracts obtained via supercritical fluid extraction. J Agric Food Chem. 2003;51:2520-5.

63. Su CC, Lin JG, Li TM, Chung JC, Yang JS, Ip SW, et al. Curcumin-induced apoptosis of human colon cancer colo 205 cells through the production of ROS, Ca2+ and the activation of caspase-3. Anticancer Res. 2006;26:4379-89.

64. Ozaki K, Kawata Y, Amano S, Hanazawa S. Stimulatory effect of curcumin on osteoclast apoptosis. Biochem Pharmacol. 2000;59:1577-81.

65. Lin SS, Huang HP, Yang JS, Wu JY, Hsia TC, Lin CC, et al. DNA damage and endoplasmic reticulum stress mediated curcumin-induced cell cycle arrest and apoptosis in human lung carcinoma A-549 cells through the activation caspases cascade- and mitochondrial-dependent pathway. Cancer Lett. 2008:272:77-90.

66. Huang AC, Chang CL, Yu CS, Chen PY, Yang JS, Ji BC, et al. Induction of apoptosis by curcumin in murine myelomonocytic leukemia WEHI-3 cells is mediated via endoplasmic reticulum stress and mitochondria-dependent pathways. Environ Toxicol. 2013;28:255-66.

67. Korwek Z, Bielak-Zmijewska A, Mosieniak G, Alster O, Moreno-Villanueva M, Burkle $A$, et al. DNA damage-independent apoptosis induced by curcumin in normal resting human T cells and leukaemic Jurkat cells. Mutagenesis. 2013;28:411-6.

68. Bush JA, Cheung Jr KJ, Li G. Curcumin induces apoptosis in human melanoma cells through a Fas receptor/caspase-8 pathway independent of p53. Exp Cell Res. 2001;271:305-14.

69. Kirana C, McIntosh GH, Record IR, Jones GP. Antitumor activity of extract of Zingiber aromaticum and its bioactive sesquiterpenoid zerumbone. Nutr Cancer. 2003;45:218-25.

70. Harliansyah H, Murad NA, Ngah WZW, Yusof YAM. Antiproliferative, antioxidant and apoptosis effects of Zingiber officinale and 6-gingerol on HepG2 cells. Asian J Biochem. 2007;2:421-6.

71. Keum YS, Kim J, Lee KH, Park KK, Surh YJ, Lee JM, et al. Induction of apoptosis and caspase-3 activation by chemopreventive [6]-paradol and structurally related compounds in KB cells. Cancer Lett. 2002;177:41-7.

72. Lee $\mathrm{E}$, Surh YJ. Induction of apoptosis in HL-60 cells by pungent vanilloids, [6]-gingerol and [6]-paradol. Cancer Lett. 1998;134:163-8.

73. Kim J. [6]-Gingerol induces apoptosis in oral cavity cancer cells. Otolaryngol Head Neck Surg. 2010;143:155-5.

74. Lee SH, Cekanova M, Baek SJ. Multiple mechanisms are involved in 6-gingerol-induced cell growth arrest and apoptosis in human colorectal cancer cells. Mol Carcinog. 2008;47:197-208.

75. Chakraborty D, Bishayee K, Ghosh S, Biswas R, Mandal SK, Khuda-Bukhsh AR. [6]-Gingerol induces caspase 3 dependent apoptosis and autophagy in cancer cells: drug-DNA interaction and expression of certain signal genes in HeLa cells. Eur J Pharmacol. 2012;694:20-9.

76. Huang HC, Chiu SH, Chang TM. Inhibitory effect of [6]-gingerol on melanogenesis in B16F10 melanoma cells and a possible mechanism of action. Biosci Biotechnol Biochem. 2011;75:1067-72.

77. Brand-Williams W, Cuvelier ME, Berset C. Use of free radical method to evaluate antioxidant activity. Lebensm Wiss Technol. 1995;28:25-30.

doi:10.1186/0717-6287-48-1

Cite this article as: Danciu et al:: Evaluation of phenolic profile, antioxidant and anticancer potential of two main representants of Zingiberaceae family against B164A5 murine melanoma cells. Biological Research 2015 48:1.

\section{Submit your next manuscript to BioMed Central and take full advantage of:}

- Convenient online submission

- Thorough peer review

- No space constraints or color figure charges

- Immediate publication on acceptance

- Inclusion in PubMed, CAS, Scopus and Google Scholar

- Research which is freely available for redistribution

Submit your manuscript at www.biomedcentral.com/submit 